\title{
BLADDER CHONDROSARCOMA IN A MALE: A RARE CASE REPORT
}

\author{
Muhammad Husni Tamrin ${ }^{1}$, Wahjoe Djatisoesanto ${ }^{2}$
}

${ }^{1}$ Resident of Urology, Dr. Soetomo General Academic Hospital, Surabaya, Indonesia

${ }^{2}$ Staff at the Department of Urology, Dr. Soetomo General Academic Hospital, Surabaya, Indonesia

\section{ABSTRACT}

Chondrosarcoma is a rare variant of bladder tumor and one of the rare types of soft tissue sarcoma. This case happened on a 36-year-old male who complained of lumps in his lower abdomen, accompanied by difficulties in passing urine and painful urination, without hematuria. We performed TURBT and histopathological examination showed low-grade chondrosarcoma. The patient was diagnosed with low-grade bladder chondrosarcoma. The patient was treated for chemotherapy and radiotherapy. However, after undergoing one cycle of chemotherapy, the patient refused to continue the therapy.

Keywords: Sarcoma; chondrosarcoma; bladder tumors; disease

\section{ABSTRAK}

Khondrosarkoma merupakan kasus yang langka pada tumor buli dan salah satu jenis sarkoma pada jaringan lunak yang jarang terjadi. Kasus ini terjadi pada pria berumur 36 tahun dengan keluhan benjolan di perut bagian bawah, disertai buang air kecil susah dan nyeri, tetapi tidak disertai hematuria. Kami lakukan tindakan TURBT dan pemeriksaan patologi anatomi dengan hasil khondrosarkoma low grade. Kami diagnosis pasien dengan khondrosarkoma buli low grade. Pasien direncanakan tindakan kemoterapi dan radioterapi, sudah menjalani kemoterapi satu siklus tetapi pasien menolak untuk melanjutkan terapi.

Kata kunci: Sarkoma; khondrosarkoma; tumor buli; disease

Correspondence: Wahjoe Djatisoesanto, Department of Urology, Dr. Soetomo General Academic Hospital, Surabaya, East Java 60286. Email: wdjatisoesanto@gmail.com

pISSN:2355-8393 • eISSN: 2599-056x • doi: 10.20473/fmi.v57i3.25208

- Fol Med Indones. 2021;57:256-261 • Submitted 03 Feb 2021 • Received 03 May $2021 \bullet$ Accepted 24 Jun 2021

- Open access under CC-BY-NC-SA license • Available at https://e-journal.unair.ac.id/FMI/ 


\section{INTRODUCTION}

Chondrosarcoma is a type of soft tissue sarcoma that rarely occurs (Kim et al 2011). It is responsible for no more than $0.5 \%$ of all bladder malignancy cases (Sule et al 2015). Bladder chondrosarcoma is a rare extraskeletal chondrosarcoma (Cho et al 2016).

A pelvic-abdominal magnetic resonance imaging (MRI) examination is able to describe bladder chondrosarcomas with clarity compared to a pelvicabdominal CT scan (He et al 2016) MRI could show tumor invasion of the pelvic-abdominal organs and internal view of the tumor (Casali \& Blay 2010).

The principle of bladder chondrosarcoma therapy is surgery, namely transurethral resection of bladder tumor (TURBT) (Richterstetter et al 2012, Miyake et al 2021). The TURBT aims to eradicate the tumor, biopsy, radical cystectomy, multidisciplinary treatment based on the histopathological subtypes, and chemoradiation (Sule et al 2015). We reported a case of low-grade bladder chondrosarcoma.

\section{CASE PRESENTATION}

A 36-year-old male patient came to the Urology Clinic with a chief complaint of a lump in the lower abdomen for the last 1.5 years. The lump was initially felt as large as a marble and it became gradually bigger to the size of a pear. The complaint was accompanied by pain, nausea, and weight loss without fever in the last six months. There were complaints of painful, dribbling urination, without blood in the urine. The patient also complained of defecating difficulties.

Based on the physical examination findings, there was a suprapubic solid mass, $\pm 20 \times 15 \times 10 \mathrm{~cm}$ in size. It had a hard consistency with tenderness, and it fixed to the surrounding tissue. Digital rectal examination indicated normal anal sphincter tone, bulbocavernosus reflex, and smooth anal mucosal layer. However, there was an extraluminal mass at the eleven to one o'clock position. The prostate was within normal limits.

The laboratory examination found hemoglobin: 8.6 g/dL, leukocytes: $8.430 / \mathrm{uL}$, and platelet: $330.000 / \mathrm{uL}$. Renal function test showed abnormal results of blood urea nitrogen (BUN) (121 mg/dL) and serum creatinine (21.56 $\mathrm{mg} / \mathrm{dL})$. The urinalysis obtained a $\mathrm{pH}$ of 6 , leucocytes: 25-50/field of view, and erythrocytes: 50100/field of view. The patient's serum electrolyte analysis showed hyperkalemia condition with a potassium level of $5.6 \mathrm{mmol} / \mathrm{L}$.

The initial radiological examination of the patient was ultrasonography (USG) (Figure 1). It showed a solid cystic mass with distinct border, and intralesional vascularization $(+)$ in the pelvic cavity measuring at $16 \times 13 \times 19 \mathrm{~cm}$. Bilateral moderate hydronephrosis was also obtained. Other abdominal organs were normal. 


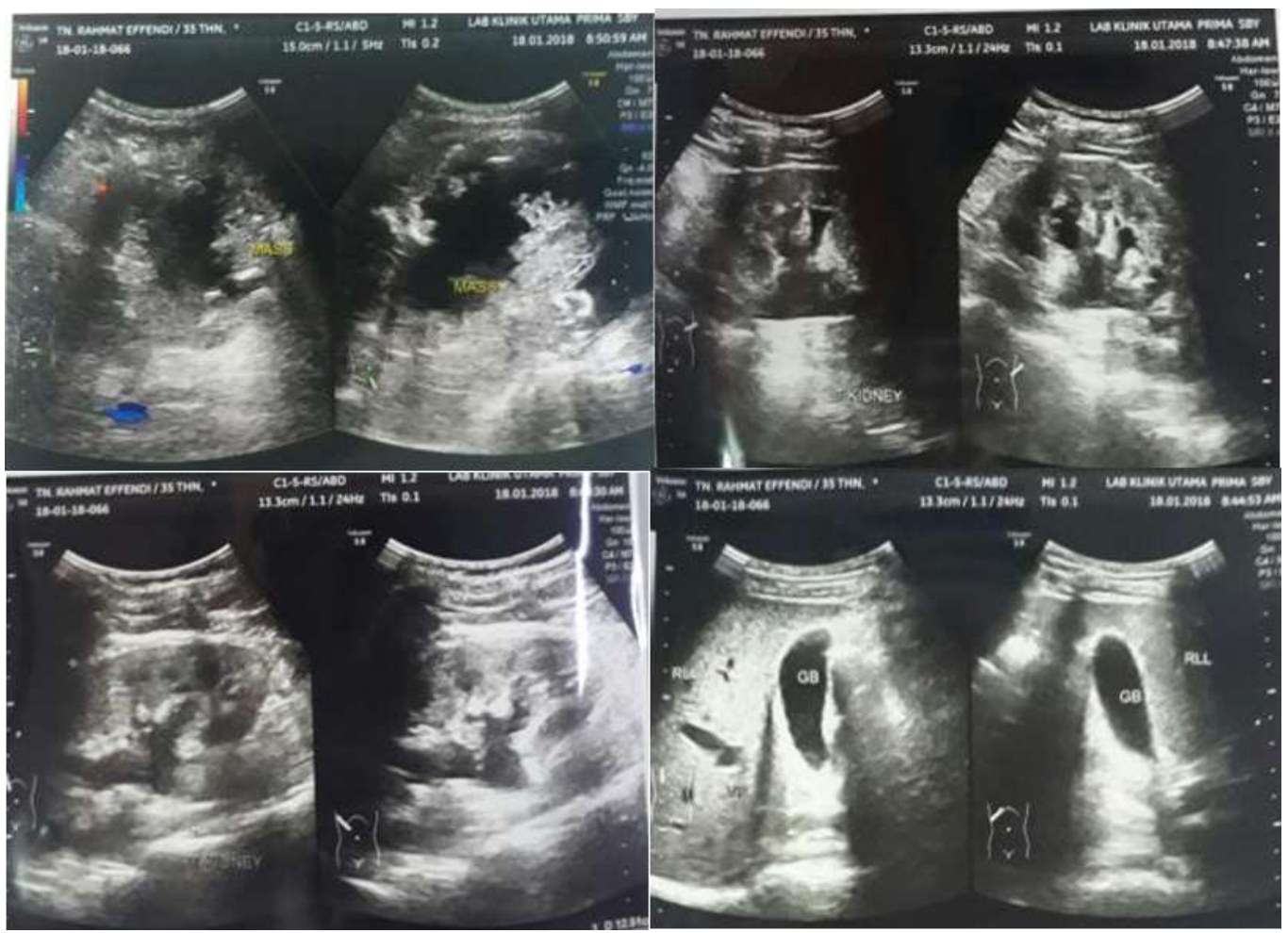

Figure 1. Ultrasonography (USG): Cystic solid mass with distinct border, and intralesional vascularization (+) in the pelvic cavity measuring at 16x13x19 cm. Bilateral moderate hydronephrosis was also shown. Other abdominal organs were normal

The magnetic resonance imaging (MRI) of the pelvicabdomen region without contrast (Figure 2), showed suspicious mass in the seminal vesicles, cystic with septa, with solid components, partially indistinct borders, lobed edges, measuring at $\pm 16 \times 10.8 \times 10.5 \mathrm{~cm}$.
The mass was attached to the inferior side of bladder, with partially indistinct borders, showed an impression of infiltration into the bladder, pressing the right and left ureters causing bilateral moderate hydronephrosis and hydroureter.

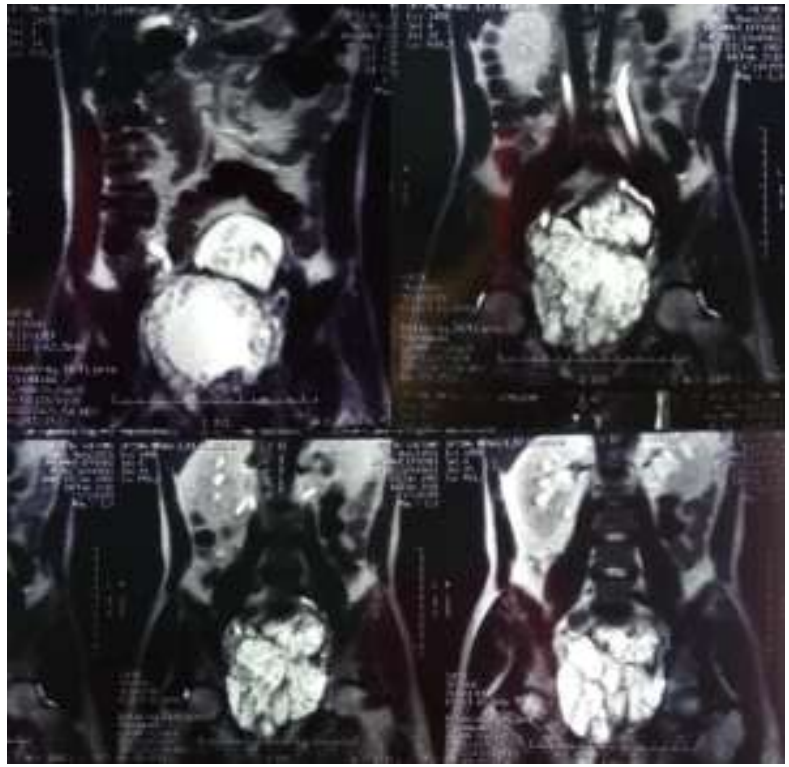

Figure 2. Magnetic resonance imaging (MRI) of the pelvic-abdomen region without contrast 
The patient was initially diagnosed with a pelvic cavity mass towards a suspicion of seminal vesicle tumor, with bilateral moderate hydronephrosis and hydroureter. The patient underwent cystoscopy, bladder, seminal vesicle biopsy, trans-rectal prostate biopsy, and right-left percutaneous nephrostomy
(PNS). At the time of cystoscopy, there was a papillary mass, exophytic from the bladder neck which occupied the entire bladder. The mass was fragile, prone to bleeding, and the ureteral opening was difficult to evaluate (Figure 3). Afterwards, a mass biopsy was performed in the bladder.

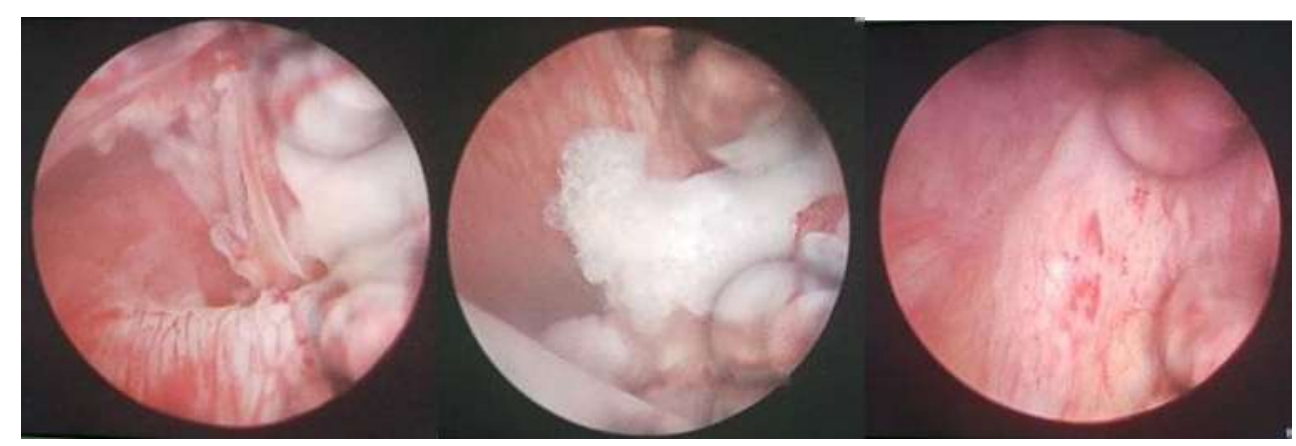

Figure 3. Cystoscopy: visible mass from the neck of the bladder which occupies the entire bladder

The patient then underwent a right-left percutaneous nephrostomy (PNS) with $20 \mathrm{cc}$ of urine from the rightleft PNS, and the urine from the left PNS was $15 \mathrm{cc}$, with clear-yellow color. USG examination (Figure 4) showed right mild hydronephrosis and percutaneous nephrostomy (PNS) with nasogastric tube (NGT) in the pelvic-calyx-system (PCS).

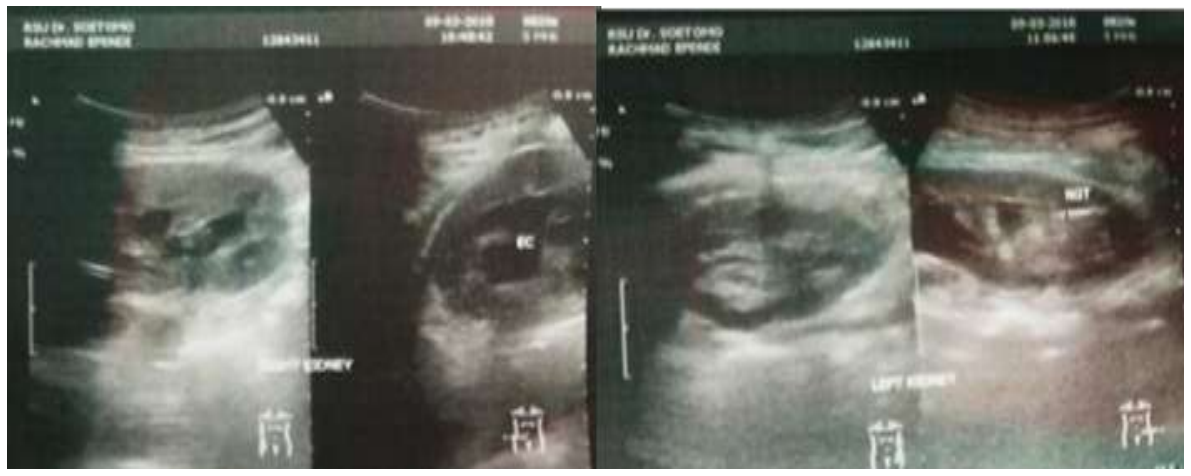

Figure 4. Ultrasonography (USG) indicating right-left mild hydronephrosis, and right-left percutaneous nephrostomy (PNS) with nasogastric tube (NGT) in the pelvic-calyx-system (PCS)

The anatomical pathology results of the biopsy confirmed the infiltrating tumor in bladder and seminal vesicles as low-grade chondrosarcoma (Figure 5). Based on the discussion of the urologist, radiologist, and anatomical pathologist, the tumor in this case was originated from the bladder, and diagnosed as bladder chondrosarcoma. This decision was also made based on the literature study that reported several bladder chondrosarcoma cases, even though it was a rare case.

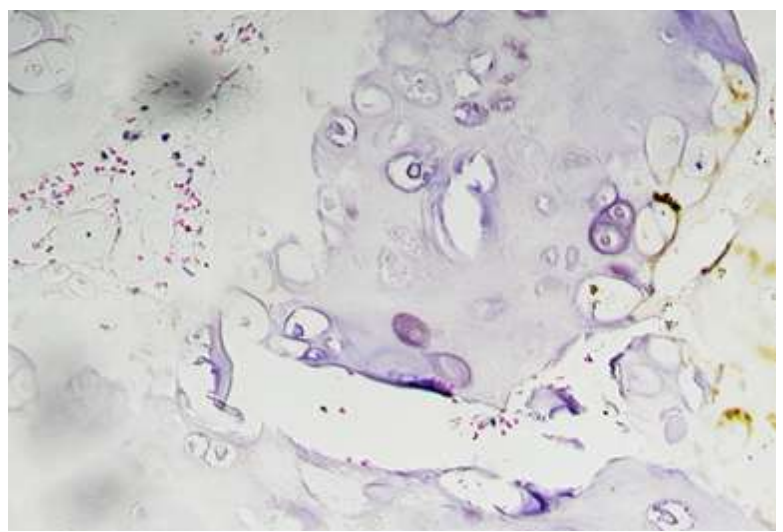


Figure 5. Histopathological results of the bladder showing transitional epithelial lining tissue and fragments of neoplastic chondroid cells with large pleiomorphic hyperchromatic nuclei and clear cytoplasm, suggesting a low grade chondrosarcoma (200x magnification)

We planned chemotherapy and radiation therapy for the patient. After one cycle of chemotherapy, the therapy was discontinued because the patient dropped out from the treatment. The patient returned after 1.5 years with recurrent complaints of dysuria, hematuria, and pain sensation in the lower abdominal area. The patient did not want to continue the chemotherapy or radiotherapy, and decided to do palliative therapy instead.

\section{DISCUSSION}

Bladder chondrosarcoma is a soft tissue tumor or sarcoma which is very rare in the bladder (Ikemoto et al 2004, Zulfariska et al 2020). The most common bladder sarcoma is leiomyosarcoma (Zieschang et al 2019), and comprising about $60-73 \%$ of all cases. Rhabdomyosarcoma and angiosarcoma are other types of sarcomas that can be found on the bladder, comprising about $20 \%$ and $15 \%$ of all cases, respectively (Gupta et al 2015).

There are only 6 reported cases of bladder chondrosarcoma in the British medical literature (Sule et al 2015). Of the cases reported, five cases complained of dysuria, urinary, frequency, and hematuria. Complaints of hematuria are found in $\pm 85 \%$ of malignancies in the bladder, either gross or microscopic hematuria (American Cancer Society 2014).

Chemotherapy agent for bladder chondrosarcoma patients according to the recommendation is doxorubicin and cisplatin accompanied by 6 cycles of GCSF (Granulocyte colony stimulating factors) prophylaxis, with a time span between 2 cycles for 21 days (von Mehren et al 2016).

The doxorubicin regimen was administered at a dose of $25 \mathrm{mg} / \mathrm{m} 2$ body surface area (BSA), intravenously in $100 \mathrm{~mL}$ of $0.9 \% \mathrm{NaCl}$ solution for 4 hours on day 1,2 , and 3 before rehydration. Cisplatin is given at a dose of $25 \mathrm{mg} / \mathrm{m} 2 \mathrm{BSA}$, administered intravenously in $1000 \mathrm{ml}$ of $0.9 \% \mathrm{NaCl}$ solution for 8 hours on day 1 and 2 after rehydration. On the 4th day, it can be given GCSF prophylaxis (Granulocyte colony stimulating factors), such as leukogen or filgrastim (Petsko 2011).

Local therapy using radiotherapy can be given before and after surgery (Baskar et al 2012), and it depended on the clinical condition of the patient, where it can also determine his radiotherapy techniques (Yoon et al 2021). Radiotherapy doses between 45-50 Gy in 25 to 28 times of administration, with integrated doses simultaneously up to a total dose of $57.5 \mathrm{~Gy}$ in 25 times of administrations. Thelimits of radiotherapy in the tumor is determined by the surgeon and the radiation oncologist (Petsko 2011).

\section{CONCLUSION}

Multimodal approaches including chemotherapy, surgery, and or radiotherapy are the principle of bladder chondrosarcoma. The intensity and timing of treatment should be planned according to each patient's condition.

\section{REFERENCES}

American Cancer Society (2014). Soft tissue sarcoma causes, risk factors, and prevention. Available from https://www.cancer.org/. Accessed March 13, 2021.

Baskar R, Lee KA, Yeo R, et al (2012). Cancer and radiation therapy: Current advances and future directions. International Journal of Medical Sciences 9, 193-199.

Casali PG, Blay JY (2010). Soft tissue sarcomas: ESMO clinical practice guidelines for diagnosis, treatment and follow-up. Annals of Oncology 21, 198-203.

Cho MH, Kim SH, Park WS, et al (2016). Bladder chondrosarcoma plus urothelial carcinoma in recurred transitional cell carcinoma of the upper urinary tract: A case report and literature review. World Journal of Surgical Oncology 14, 1-4.

Gupta SR, Saran RK, Sharma P, et al (2015). A rare case of extraskeletal mesenchymal chondrosarcoma with dedifferentiation arising from the buccal space in a young male. Journal of Maxillofacial and Oral Surgery 14, 293-299.

He Z, Sha N, Qi S-Y, et al (2016). Primary chondrosarcoma of the prostate: A case report. International Journal of Clinical and Experimental Pathology 9, 2512-2515.

Ikemoto S, Sugimura K, Yoshida N, et al (2004). Chondrosarcoma of the urinary bladder and establishment of a human chondrosarcoma cell line (OCUU-6). Human Cell 17, 93-96.

Kim M-J, Cho K-J, Ayala AG, et al (2011). Chondrosarcoma: With updates on molecular genetics. Sarcoma 2011, 1-16.

Miyake M, Nishimura N, Inoue T, et al (2021). Fluorescent cystoscopy-assisted en bloc transurethral resection versus conventional transurethral resection in patients with non-muscle invasive bladder cancer: study protocol of a prospective, open-label, 
randomized control trial (the FLEBER study). Trials 22, 1-10.

Petsko GA (2011). NCCN clinical practice guidelines in oncology (NCCN GuidelinesTM) soft tissue sarcoma version 1.2011. Genome Biology 8, 1-82.

Richterstetter M, Wullich B, Amann K, et al (2012). The value of extended transurethral resection of bladder tumour (TURBT) in the treatment of bladder cancer. BJU Int 110, E76-E79.

Sule N, Xu B, Zein DE, et al (2015). Radiation-induced chondrosarcoma of the bladder. Case report and review of literature. Anticancer Research 35, 28572860 .

von Mehren M, Randall RL, Benjamin RS, et al (2016). Soft Tissue sarcoma, version 2.2016, NCCN clinical practice guidelines in oncology. J Natl Compr Canc Netw 14, 758-86.

Yoon SM, Chu F-I, Ruan D, et al (2021). Assessment of toxic effects associated with dose-fractionated radiotherapy among patients with cancer and comorbid collagen vascular disease. JAMA Netw Open 4, 1-14.

Zieschang H, Koch R, Wirth MP, et al (2019). Leiomyosarcoma of the urinary bladder in adult patients: A systematic review of the literature and meta-analysis. Urol Int 102, 96-101.

Zulfariska N, Martadiani ED, Wiratnaya IGE, et al (2020). Variasi kondrosarkoma pada usia muda: Serial kasus. MEDICINA 51, 567-570. 